Architects of the Self 



\section{Architects of the Self}

George Eliot, D. H. Lawrence,

and E. M. Forster

BY CALVIN BEDIENT

UNIVERSITY OF CALIFORNIA PRESS BERKELEY - LOS ANGELES - LONDON 1972 


\section{University of California Press}

Berkeley and Los Angeles, California

University of California Press, Ltd.

London, England

Copyright $\odot 1972$ by The Regents of the University of California ISBN: $0-520-01873-7$

Library of Congress Catalog Card Number: 70-142056

Printed in the United States of America 
for Vanessa 
